\title{
Changes in pulsatile LH secretion and the positive and negative feedback actions of oestradiol after administration of a GnRH agonist in the ovariectomized ewe
}

\author{
B. P. Fitzgerald, H. I'Anson*, R. G. Loy and S. J. Legan* \\ Departments of Veterinary Science and *Physiology and Biophysics, University of Kentucky, \\ Lexington, Kentucky 40546-0076, U.S.A.
}

\begin{abstract}
Summary. Administration of a $\mathrm{GnRH}$ agonist $(5 \mu \mathrm{g})$ every $12 \mathrm{~h}$ to long-term ovariectomized ewes for 5 or 10 days during the breeding season suppressed mean LH levels from around 6 to $1 \mathrm{ng} / \mathrm{ml}$ on Days 1 and 4 after treatment; on Day 1 after treatment $\mathrm{LH}$ pulse frequency and amplitude were lower than pretreatment values. On Day 4 after treatment $\mathrm{LH}$ pulse frequency was restored to pretreatment levels ( 1 per $\mathrm{h}$ ) whereas LH pulse amplitude had only slightly increased from 0.5 to $1 \mathrm{ng} / \mathrm{ml}$, a value $25 \%$ of that before treatment. This increase in amplitude was greater the shorter the duration of treatment. Ovariectomized ewes treated with the agonist for 5 days exhibited both negative and positive feedback actions after implantation of a capsule containing oestradiol; however, compared to control ewes treated with oestradiol only, the positive and negative feedback actions of oestradiol were blunted.

These results suggest that the recovery of tonic LH concentrations after GnRH agonist-induced suppression is limited primarily by changes in LH pulse amplitude. The results also demonstrate that the feedback actions of oestradiol are attenuated, but not blocked, by GnRH agonist treatment.
\end{abstract}

\section{Introduction}

Although acute or intermittent administration of gonadotrophin-releasing hormone (GnRH) stimulates gonadotrophin secretion, chronic treatment with GnRH or long-acting agonists paradoxically inhibits reproductive function in males and females of a variety of species (Vale, Rivier, Rivier \& Brown, 1977; Hsueh \& Jones, 1981 ; Fraser, 1982). Amongst the many potential uses of GnRH agonists is the synchronization of ovulation. For example, it has been demonstrated that repeated administration of a GnRH agonist to rats induced acyclicity and was succeeded by a synchronous ovulation shortly after cessation of treatment (Vickery \& McRae, 1980). In the cow, chronic administration of GnRH agonist also blocked ovulation (Herschler \& Vickery, 1981). However, it is not known whether the reinitiation of oestrous cycles also occurs synchronously.

The mechanism whereby GnRH or its agonists elicit inhibitory effects on reproductive function is also unknown. It has been proposed that the high levels of circulating GnRH may act directly on the gonad to suppress its function (Hsueh \& Jones, 1981; Fraser, 1982). Alternatively, the chronic elevation of serum gonadotrophin concentrations may reduce the responsiveness of gonadal target cells (Hsueh, Dufau \& Catt, 1976; Rao, Richards, Midgley \& Reichert, 1977; Fraser \& Lincoln, 1980). Chronic high levels of GnRH may also act directly on the pituitary gland to decrease its response to $\mathrm{GnRH}$ with a resultant suppression of gonadotrophin secretion (Fraser \& Lincoln, 1980; Hsueh \& Jones, 1981). 
The present study was conducted to determine the effects of chronic GnRH treatment on the hypothalamic-pituitary axis, and thereby to investigate the potential application of GnRH agonist to synchronize ovulation in the ewe.

\section{Materials and Methods}

\section{Animals}

Twenty Southdown $\times$ Finnish Landrace ewes, which had been ovariectomized 1 year previously, were maintained in natural environmental conditions. They were fed hay and corn daily, and water was supplied ad libitum. During periods of blood collection, the ewes were housed in a covered, 3-sided shed.

\section{Treatments}

During the breeding season ( 5 January), the 20 ewes were randomly allocated to four equal

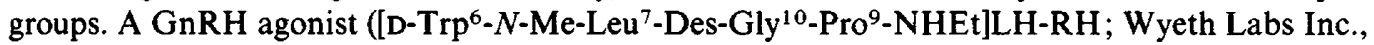
Philadelphia, Pennsylvania, USA) was administered i.v. at 12-h intervals for 5 (Group I) or 10 (Group II) days. This agonist is 20-200 times more potent than GnRH (Corbin et al., 1979). The dose of agonist $(5 \mu \mathrm{g} /$ ewe in $1 \mathrm{ml} 0.9 \%(\mathrm{w} / \mathrm{v}) \mathrm{NaCl}$ containing $0.1 \%$ gelatin) was chosen on the basis of a preliminary dose-response trial in which this dose induced a sustained increase in serum LH concentrations for $12 \mathrm{~h}$.

To examine the effect of treatment with GnRH agonist on the positive and negative feedback actions of oestradiol on LH secretion, an additional 5 ewes (Group III) received $5 \mu \mathrm{g} \mathrm{GnRH}$ agonist every $12 \mathrm{~h}$ for 5 days. Thereafter, a Silastic (Dow Corning, Midland, MI, U.S.A.) capsule containing oestradiol-17ß, constructed as described previously (Karsch \& Foster, 1975), and designed to produce serum levels of about $5 \mathrm{pg}$ oestradiol $/ \mathrm{ml}$, was inserted s.c. at 10:00 h on Day 6, $12 \mathrm{~h}$ after the last injection of GnRH agonist. The remaining 5 untreated ewes (Group IV) also received an oestradiol implant at this time, thus serving as controls for Group III.

\section{Collection of blood samples}

To determine the effect of administration and withdrawal of GnRH agonist on LH pulse frequency and amplitude, blood samples $(4 \mathrm{ml})$ were collected by jugular venepuncture every $15 \mathrm{~min}$ for $6 \mathrm{~h}$ from ewes of Groups I and II on Day - 1 (Day 1 = first day of treatment) and on the 1 st and 4th days after stopping treatment (Days 6 and 9 and Days 11 and 14 respectively for Groups I and II), hereafter referred to as Days 1 and 4 after treatment.

To examine changes in pituitary response to $\mathrm{GnRH}$ agonist during the 10 -day period of agonist treatment, blood samples $(3 \mathrm{ml})$ were collected by jugular venepuncture from the ewes of Group II during a 14-h period on Days 1, 5 and 10 of treatment. Samples were collected every 15 min during a 2-h period both before and after injection of $\mathrm{GnRH}$ agonist at 10:00 h, and at 30-min intervals for the remaining $10 \mathrm{~h}$.

Blood samples $(5 \mathrm{ml})$ were collected from the ewes of Groups III and IV by jugular venepuncture immediately before insertion of oestradiol implants and at 4-h intervals thereafter for $48 \mathrm{~h}$. Additional blood samples $(5 \mathrm{ml})$ were collected daily at $08: 00 \mathrm{~h}$ from Group IV ewes during the 5 days before implant insertion.

All blood samples were kept overnight at $4^{\circ} \mathrm{C}$. Sera were collected and stored at $-20^{\circ} \mathrm{C}$ until assayed.

\section{Radioimmunoassay of $\mathrm{LH}$}

LH concentrations were determined in duplicate 2-200 $\mu \mathrm{l}$ samples of serum using a previously described radioimmunoassay (Niswender, Reichert, Midgley \& Nalbandov, 1969). Serum LH 
concentrations were expressed in terms of the NIAMDD ovine reference preparation, batch 21. The potency of this preparation is 1.86 times that of NIH-LH-S12, as we have determined by radioimmunoassay. The sensitivity of the assays $(95 \%$ confidence limits of buffer controls) averaged $0.1 \mathrm{ng} / \mathrm{ml}$. Intra- and inter-assay coefficients of variation were 8 and $14 \%$ respectively, determined in $48 \mu \mathrm{l}$ samples of an ovariectomized ewe serum pool which bound at $50 \%$.

\section{Analysis of data}

LH pulses were identified using the three criteria previously described by Goodman \& Karsch (1980). Briefly, a pulse was identified if: (a) the peak concentration associated with the pulse occurred within two samples of the previous nadir; (b) the amplitude of the pulse exceeded the sensitivity of the assay; and (c) the LH level at the peak exceeded the $95 \%$ confidence limits of the LH concentration at both the preceding and subsequent nadirs.

Confidence limits for assay duplicates were determined using the method of Duddleson, Midgley \& Niswender (1972).

In each 6-h period, mean serum $\mathrm{LH}$ concentrations and $\mathrm{LH}$ pulse frequency and amplitude were determined for each ewe. A frequency value of zero was assigned in those instances when no LH pulses were detected. These values were then used to calculate group means ( \pm s.e.m.) and to determine statistical differences between and within groups by a split-plot analysis of variance or, when appropriate, Student's unpaired or paired $t$ test.

\section{Results}

The first injection of $5 \mu \mathrm{g}$ agonist resulted in a marked increase in serum LH concentrations from $5.0 \pm 0.9 \mathrm{ng} / \mathrm{ml}$ during the $2-\mathrm{h}$ pretreatment period to a maximum of $189.4 \pm 44.3 \mathrm{ng} / \mathrm{ml}$, which occurred $105 \mathrm{~min}$ later (Text-fig. 1). Serum LH gradually decreased thereafter to reach preinjection

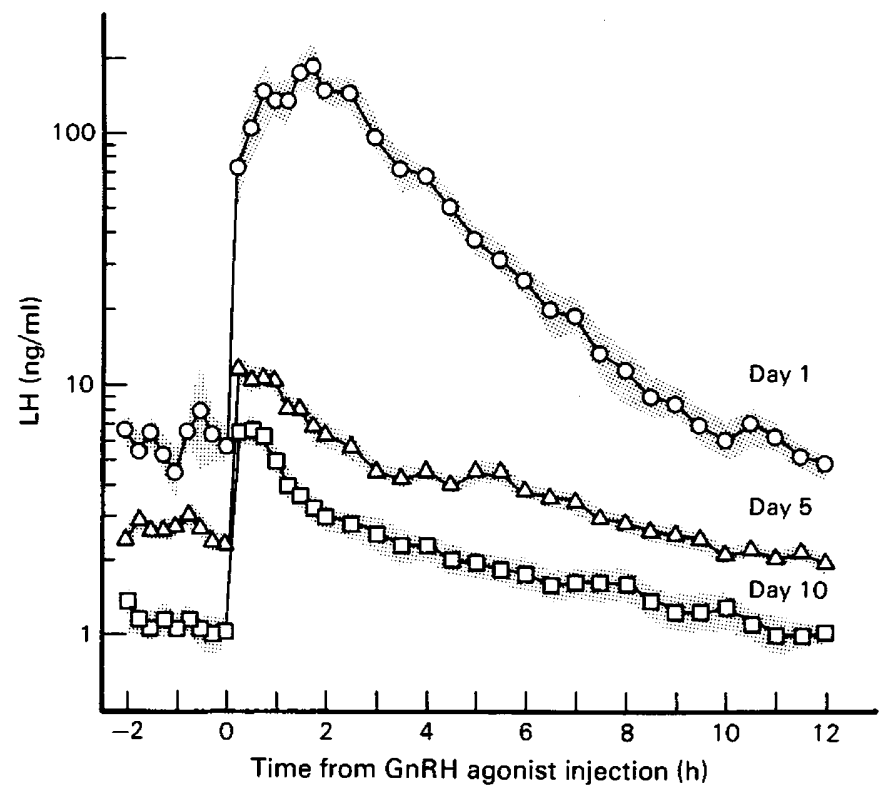

Text-fig. 1. Changes in mean ( \pm s.e.m.) serum LH concentrations in 5 ovariectomized ewes before and after the 1st, 9th and 19th successive injection (i.v.) of $5 \mu \mathrm{g} \mathrm{GnRH}$ agonist on Days 1,5 and 10 respectively. On each day samples were obtained every $15 \mathrm{~min}$ for $2 \mathrm{~h}$ before and after injection and every $30 \mathrm{~min}$ for the remaining $10 \mathrm{~h}$. 
levels by $10 \mathrm{~h}$ after injection. As indicated by the area under the response curve (corrected for preinjection levels), repeated injection of a GnRH agonist was associated with a progressive decrease in pituitary response on Days 5 and 10 (Day $1>$ Day $5, P<0.001$; Day $5>$ Day $10, P<$ 0.01 ). As illustrated in Text-fig. 1, this progressive decrease in pituitary response was also reflected in preinjection serum $\mathrm{LH}$ levels on the respective days such that they were lower on Day $5(2.6 \pm 0 \cdot 1$ $\mathrm{ng} / \mathrm{ml})$ than on Day $1(5.9 \pm 0.9 \mathrm{ng} / \mathrm{ml}, P<0.05)$ and on Day 10 were lowest $(1.1 \pm 0.1 \mathrm{ng} / \mathrm{ml}$; Day 5 vs Day $10, P<0.001)$.

Since no differences in mean serum LH concentrations or LH pulse frequency were observed between ewes of Groups I and II before or at any time after treatment $(P>0.05)$, these measurements for the 2 groups were combined. Mean serum LH concentrations were similar $(P>0.05)$ on Days 1 and 4 after treatment (Day 1, $1 \cdot 1 \pm 0 \cdot 1$; Day $4,1 \cdot 1 \pm 0 \cdot 6 \mathrm{ng} / \mathrm{ml}$ ) and on both days were lower $(P<0.001)$ than those observed before treatment (Day $-1,5.7 \pm 0.8 \mathrm{ng} / \mathrm{ml})$ (Text-fig. 2). A

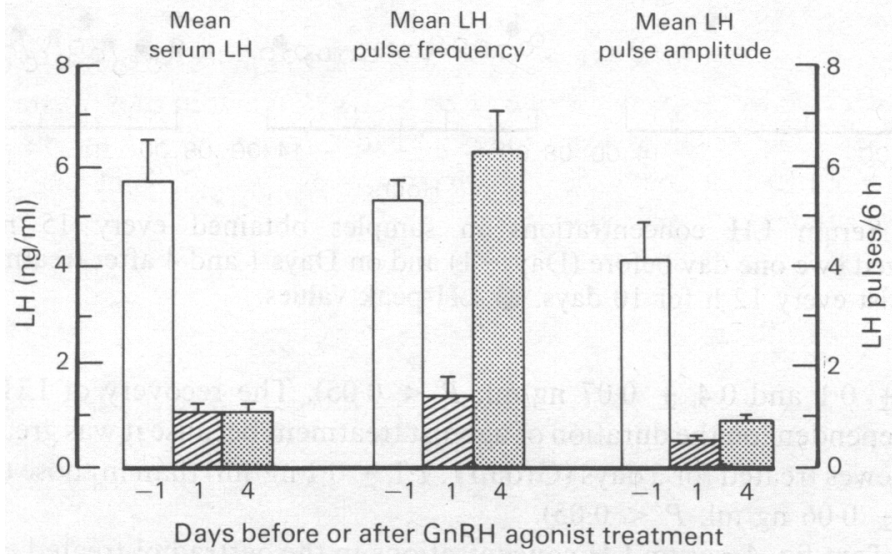

Text-fig. 2. Changes in mean ( \pm s.e.m.) serum LH concentrations, LH pulse frequency and LH pulse amplitude in samples obtained every $15 \mathrm{~min}$ from 10 ovariectomized ewes during a 6-h period before, 1 day and 4 days after administration of $5 \mu \mathrm{g}$ GnRH agonist every $12 \mathrm{~h}$ for 5 or 10 days. Mean LH pulse amplitude on Days 1 and 4 after treatment represents data obtained from 9 ewes which exhibited LH pulses on the respective days.

suppression of mean LH levels was also observed in the 2-h pretreatment period on the 5th treatment day but the value was still higher than that on the first day after stopping treatment $(2 \cdot 6$ \pm 0.2 and $1.1 \pm 0.1 \mathrm{ng} / \mathrm{ml}, P<0.001$ ). In contrast to the similarity in mean LH levels on Days 1 and 4 after treatment, the frequent collection of samples revealed striking differences in the pattern of LH secretion between the two post-treatment days and between the pre- and post-treatment periods. The secretory LH profiles on Days -1 and Days 1 and 4 after treatment for a representative ewe treated for 10 days are illustrated (Text-fig. 3).

Before treatment (Day -1 ), pulsatile LH release was observed in all ewes with a frequency of $5 \cdot 3 \pm 0.4$ pulses per $6 \mathrm{~h}$ (Text-fig. 2). On the first post-treatment day, however, the frequency was reduced $(P<0.001)$ to $1.4 \pm 0.3$ pulses per $6 \mathrm{~h}(\mathrm{~N}=10)$ and in one ewe LH pulses were absent. This reduction in LH pulse frequency was temporary since by Day 4 after treatment the frequency was not different $(P>0.05)$ from that before treatment $(6.3 \pm 0.8$ pulses per $6 \mathrm{~h}, \mathrm{~N}=10)$, although it was variable; in 9 ewes the frequency ranged between 5 and 10 per $6 \mathrm{~h}$ whereas no pulses were observed in one ewe that had previously exhibited one low-amplitude LH pulse on Day 1 after treatment.

In those ewes that exhibited LH pulses on Day -1 and on Day 1 after treatment $(N=9)$, pulse amplitude was markedly reduced (Day $-1,4.1 \pm 0.9 \mathrm{ng} / \mathrm{ml}$; Day $1,0.4 \pm 0.1 \mathrm{ng} / \mathrm{ml} ; P<0.001$ ). LH pulse amplitude was also higher on Day 4 than Day 1 in the 8 ewes that exhibited LH pulses on 


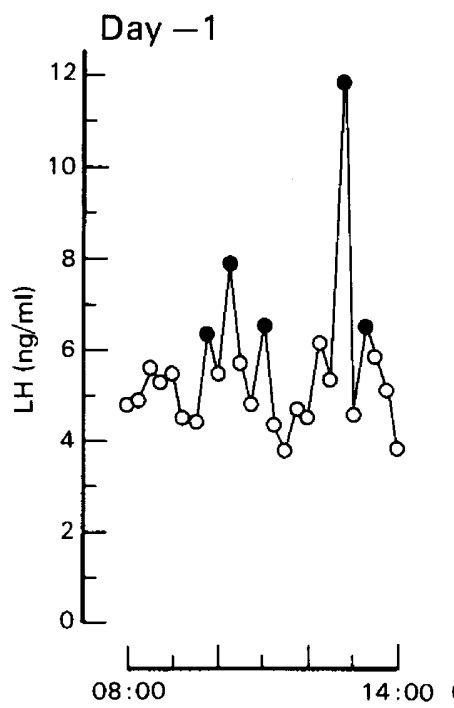

Day 1

Day 4

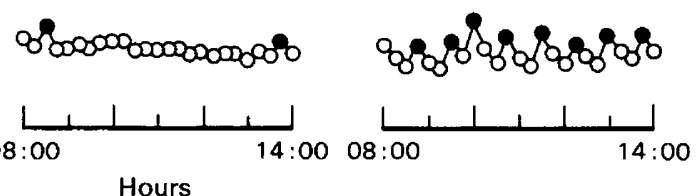

Text-fig. 3. Serum LH concentrations in samples obtained every $15 \mathrm{~min}$ from an ovariectomized ewe one day before (Day -1 ) and on Days 1 and 4 after treatment with $5 \mu \mathrm{g}$ GnRH agonist every $12 \mathrm{~h}$ for 10 days. $\mathrm{LH}$ peak values.

both days $(0.9 \pm 0.1$ and $0.4 \pm 0.07 \mathrm{ng} / \mathrm{ml}, P<0.05)$. The recovery of LH pulse amplitude appeared to be dependent on the duration of agonist treatment because it was greater on Day 4 after treatment in the ewes treated for 5 days (Group I; $1 \cdot 1 \pm 0 \cdot 1 \mathrm{ng} / \mathrm{ml}$ ) than in those treated for 10 days (Group II; $0.7 \pm 0.06 \mathrm{ng} / \mathrm{ml}, P<0.05$ ).

As shown in Text-fig. 4, serum LH concentrations in the oestradiol-treated ewes not receiving

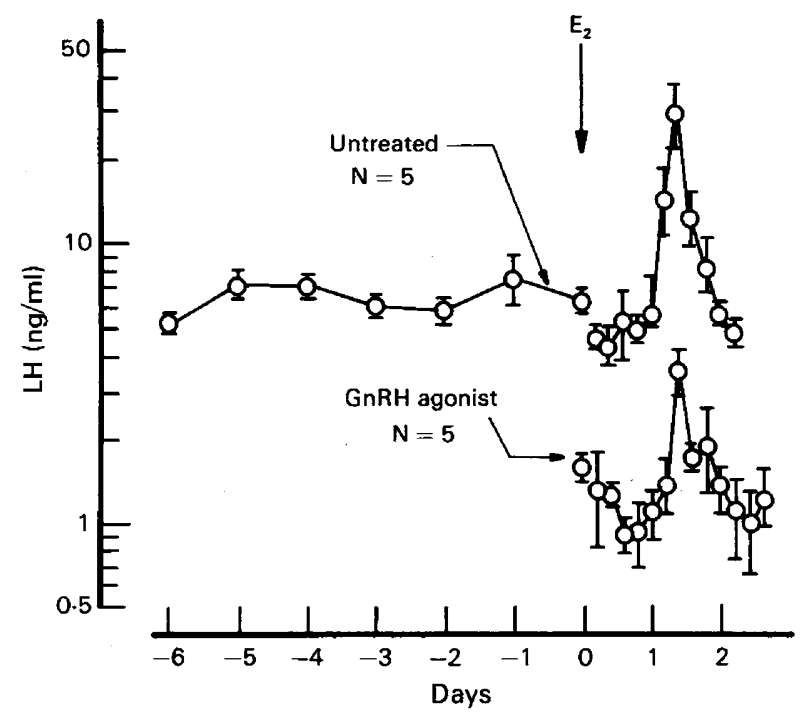

Text-fig. 4. Effect of administration of GnRH agonist $(5 \mu \mathrm{g})$ every $12 \mathrm{~h}$ for 5 days to ovariectomized ewes on the feedback actions of oestradiol $\left(E_{2}\right)$ on serum LH. Oestradiol was administered by s.c. implant $12 \mathrm{~h}$ after withdrawal of $\mathrm{GnRH}$ agonist. Values before oestradiol administration were normalized to the day of implant insertion, whereas values after oestradiol administration were normalized to the LH peak. Values are mean \pm s.e.m. 
GnRH agonist (Group IV) averaged $6.4 \pm 0.3 \mathrm{ng} / \mathrm{ml}$ during the 6 pretreatment days. As expected, serum LH concentrations initially decreased from $6.2 \pm 0.7 \mathrm{ng} / \mathrm{ml}$ at the time of insertion of the implant to $3.4 \pm 0.1 \mathrm{ng} / \mathrm{ml}, 10.4 \pm 2.0 \mathrm{~h}$ later (range $4-16 \mathrm{~h}$ ). The oestradiol-induced $\mathrm{LH}$ increment $(29.8 \pm 7.9 \mathrm{ng} / \mathrm{ml}$ ) occurred $32.8 \pm 4.0 \mathrm{~h}$ (range $24-44 \mathrm{~h}$ ) after implant insertion.

In Group III (GnRH + oestradiol implant) there was a typical biphasic modulation of serum $\mathrm{LH}$ concentrations; first, a negative feedback-induced suppression from $1.6 \pm 0.4 \mathrm{ng} / \mathrm{ml}$ at the time of implant insertion (10:00 h on Day 1 after treatment) to $0.6 \pm 0.1 \mathrm{ng} / \mathrm{ml}$ (range $0.3-1.2$ $\mathrm{ng} / \mathrm{ml}$ ) within $8 \mathrm{~h}$ of implant insertion. This was followed by a positive feedback-induced increment in LH levels to a maximum of $3.5 \pm 0.6 \mathrm{ng} / \mathrm{ml}$ by $27.2 \pm 4.4 \mathrm{~h}$ (range 20-44 $\mathrm{h}$ ) after implant insertion. This 6 -fold rise in $\mathbf{L H}$ concentrations occurred at about the same time as the $\mathrm{LH}$ rise in the control ewes $(P>0 \cdot 05)$.

\section{Discussion}

It has been recognized for several years that pulsatile GnRH stimulation of the pituitary gland is able to sustain $\mathrm{LH}$ release whereas a continuous mode of GnRH administration paradoxically suppresses LH levels (Knobil, 1980). A similar refractoriness of the pituitary gland to GnRH stimulation has been demonstrated in several species following repeated or continuous administration of high doses of GnRH or GnRH agonists (Chakraborty, Adams, Tarnavsky \& Reeves, 1974; Davies et al., 1977; Rivier \& Vale, 1979). Studies of monkeys and sheep have revealed that very frequent intermittent delivery of physiological doses of $\mathrm{GnRH}$, at a rate of two pulses per $h$, also leads to pituitary refractoriness (Wildt et al., 1981; Kaynard \& Karsch, 1983). The present study confirms earlier reports that treatment of ovariectomized ewes with continuous or intermittent administration of GnRH results in pituitary refractoriness to GnRH (Rippel, Johnson \& White, 1974; Nett, Crowder, Moss \& Duello, 1981). Our observations extend these studies by documenting changes in tonic LH secretion and oestradiol feedback effects during the recovery from chronic GnRH agonist treatment and suggest that the ability of a GnRH agonist to suppress serum LH levels maximally in the ovariectomized ewe is dependent on the duration of treatment.

Since serum LH concentrations were maximally suppressed on the day after 5 days of agonist treatment, but not on the morning of the 5th treatment day, the present results suggest that a minimum of 5 days of repeated agonist treatment is necessary to suppress serum LH to a nadir. In support of this observation, Nett et al. (1981) reported that LH levels in ovariectomized ewes were similar to pretreatment values at the end of $24 \mathrm{~h}$ of continuous GnRH infusion, whereas Rippel et al. (1974) observed a reduction in LH to about half pretreatment levels in ovariectomized ewes immediately before the 4th and final daily injection of a high dose of GnRH.

Although serum LH levels were suppressed to $1 \mathrm{ng} / \mathrm{ml}$ by the agonist treatment, a mean level similar to that in anoestrous ewes, the pattern of secretion was different from that observed during anoestrus. In the agonist-treated ewes the levels between pulses were about $1 \mathrm{ng} / \mathrm{ml}$ and the pulse amplitude was very low, whereas in anoestrous ewes, serum LH levels between pulses are generally undetectable and the pulses are of greater amplitude (Goodman, Bittman, Foster \& Karsch, 1982). A longer period of agonist treatment might suppress serum LH levels still further in such long-term ovariectomized ewes.

With regard to the changes in tonic LH secretion during the recovery from GnRH agonist treatment, the foregoing results suggest that, although LH pulse frequency is suppressed initially, it recovers to pretreatment levels within the next 3 days. This reduction in LH pulse frequency might be interpreted to indicate that GnRH agonist treatment modifies GnRH pulse frequency. Alternatively, pulse frequency may not have been altered by the treatment, but the slower recovery of LH pulse amplitude may have prevented detection of pulses by current assay methods. Consideration should also be given to the possibility that samples were collected too infrequently (every 15 min) to identify small rises in LH concentration. Karsch, Foster, Bittman \& Goodman (1983) 
demonstrated that, when LH pulse frequency is rapid and pulse amplitude low, pulse frequency may be underestimated in samples collected every 12 min compared to that determined from samples collected at 4-min intervals. Therefore, it remains to be determined whether the observed changes in pulse frequency and amplitude reflect an alteration in endogenous pulsatile GnRH output or whether these observations are due solely to a suppression of pituitary response to GnRH. That a decrease in pituitary response is responsible, at least in part, for the suppression of LH pulse amplitude is supported by the observation of a decrease in response to GnRH agonist during the course of treatment.

Despite an increase in LH pulse frequency, coupled with an increase in pulse amplitude on Day 4 after treatment, mean serum LH levels were the same as on Day 1 after treatment and remained lower than before treatment. This probably reflects the low amplitude of the $\mathrm{LH}$ pulses. The present results suggest that the recovery of serum LH concentrations to pretreatment levels is mainly, if not completely, amplitude-modulated. If so, such a mechanism of control of tonic LH concentrations contrasts with the physiological regulation of tonic LH concentrations during the oestrous cycle, which is achieved by reciprocal modulation of LH pulse frequency and amplitude (Goodman \& Karsch, 1980; Baird \& McNeilly, 1981) and with that occurring immediately after ovariectomy when pulse frequency and amplitude increase (Goodman et al., 1982).

In intact anoestrous ewes, repeated administration of high doses of $\mathrm{GnRH}$ for 7 days blocked the positive feedback action of oestradiol on LH release (Rippel et al., 1974). In contrast, the present study demonstrates that in ovariectomized ewes neither the negative nor the positive feedback actions of oestradiol are blocked by chronic GnRH agonist treatment, although they are markedly suppressed. That the modulations of serum LH resulting from an oestradiol increment reflect both negative and positive feedback effects in the GnRH agonist-treated ewes is suggested by the timing of the changes relative to those observed in control ewes, which only received an oestradiol implant. In the latter animals, the magnitude of the oestradiol-induced LH surge was considerably smaller than that previously reported (Karsch \& Foster, 1975). The reason for this difference is not known but may reflect potency of standards for LH measurement and/or breeds of sheep used in the respective studies.

The investigation reported in this paper (84-4-139) is in connection with a project of the Kentucky Agricultural Experiment Station and is published with the approval of the Director. We thank Ms M. VanArsdall and Ms C. Gatus for valuable assistance in collection of blood samples; Dr T. M. Nett, Dr L. E. Reichert, Jr, and Dr L. Edgerton for RIA reagents; Dr R. L. Goodman and Dr K. D. Ryan for their valuable criticism and assistance in the design of the study; and Dr F. Bex, Wyeth Labs, Inc., for the gift of GnRH agonist. Supported in part by NIH-HD-14039 to Dr S. J. Legan and a grant from the Grayson Foundation, Inc., to Dr R. G. Loy.

\section{References}

Baird, D.T. \& McNeilly, A.S. (1981) Gonadotrophic control of follicular development and function during the oestrous cycle of the ewe. J. Reprod. Fert., Suppl. 30, 119-133.

Chakraborty, P.K., Adams, T.E., Tarnavsky, G.K. \& Reeves, J.R. (1974) Serum and pituitary LH concentrations in ewes infused with LH-RH/FSH-RH. $J$. Anim. Sci. 39, 1150-1157.

Corbin, A., Bex, F.J., Yardley, J.P., Rees, R.W., Foell, T.J. \& Sarantakis, D. (1979) Agonist (ovulation induction) and post-coital contraceptive properties of (D-Ala ${ }^{6}$ - and (D-Tryp 6 ]-LHRH series. Endocr. Res. Comm. 6, 1-14.
Davies, T.F., Gomez-Pan, A., Watson, M.J., Mountjoy, C.Q., Hanker, J.P., Besser, G.M. \& Hall, R. (1977) Reduced response to gonadotrophin-releasing hormone after long-term administration to impotent men. Clin. Endocr. 6, 213-218.

Duddleson, W.G., Midgley, A.R., Jr \& Niswender, G.D. (1972) Computer program sequence for analysis and summary of radioimmunoassay data. Comp. Biomed. Res. 5, 205-217.

Fraser, H.M. (1982) Antifertility effects of GnRH $J$. Reprod. Fert. 64, 503-515.

Fraser, H.M. \& Lincoln, G.A. (1980) Effects of chronic treatment with an LHRH agonist on the secretion of Downloaded from Bioscientifica.com at 04/26/2023 11:06:41AM 
LH, FSH and testosterone in the ram. Biol. Reprod. 22, 269-276.

Goodman, R.L. \& Karsch, F.J. (1980) Pulsatile secretion of luteinizing hormone: differential suppression by ovarian steroids. Endocrinology 107, 1286-1290.

Goodman, R.L., Bittman, E.L., Foster, D.L. \& Karsch, F.J. (1982) Alterations in the control of LH-pulse frequency underlie the seasonal variation in estradiol negative feedback in the ewe. Biol. Reprod. 27, 580589.

Herschler, R.C. \& Vickery, B.H. (1981) Effects of (DTrp ${ }^{6}$-DesGly ${ }^{10}$-ProNH ${ }_{2}^{9}$-luteinizing hormone-releasing hormone ethylamide on the estrous cycle, weight gain, and feed efficiency in feedlot heifers. Am. J. vet. Res. 42, 1405-1408.

Hsueh, A.J.W. \& Jones, P.B.C. (1981) Extrapituitary actions of gonadotropin releasing hormone. Endocrine Rev. 2, 437-461.

Hsueh, A.J.W., Dufau, M.L. \& Catt, K.J. (1976) Regulation of luteinizing hormone receptors in testicular interstitial cells by gonadotropin. Biochem. Biophys. Res. Commun. 72, 1145-1152.

Karsch, F.J. \& Foster, D.L. (1975) Sexual differentiation of the mechanism controlling the preovulatory discharge of luteinizing hormone in sheep. Endocrino$\log y$ 97, 373-379.

Karsch, F.J., Foster, D.L., Bittman, E.L. \& Goodman, R.L. (1983) A role for estradiol in enhancing luteinizing hormone pulse frequency during the follicular phase of the estrous cycle of sheep. Endocrinology 113, 1333-1339.

Kaynard, A.H. \& Karsch, F.J. (1983) The inverse relationship between $\mathrm{LH}$-pulse amplitude and frequency in the ewe may reflect a change in pituitary response to GnRH. Biol. Reprod. 28, Suppl. 1, Abstr. 65.
Knobil, E. (1980) The neuroendocrine control of the menstrual cycle. Recent Prog. Horm. Res. 36, 53-88.

Nett, T.M., Crowder, M.E., Moss, G.E. \& Duello, T.M. (1981) GnRH-receptor interaction. V. Down-regulation of pituitary receptors for GnRH in ovariectomized ewes by infusion of homologous hormone. Biol. Reprod. 24, 1145-1155.

Niswender, G.D., Reichert, L.E., Jr, Midgley, A.R., Jr \& Nalbandov, A.V. (1969) Radioimmunoassay for bovine and ovine luteinizing hormone. Endocrinology 84, 1166-1173.

Rao, M.C., Richards, J.S., Midgley, A.R., Jr \& Reichert, L.E., Jr (1977) Regulation of gonadotropin receptors by luteinizing hormone in granulosa cells. Endocrino$\log y 101,512-523$.

Rippel, R.H., Johnson, E.S. \& White, W.F. (1974) Effect of consecutive injections of synthetic gonadotropinreleasing hormone on $\mathrm{LH}$ release in the anestrous ewe and ovariectomized ewe. J. Anim. Sci. 39, 907-914.

Rivier, C. \& Vale, W. (1979) Hormonal secretion in male rats chronically treated with $\left(\mathrm{D}-\mathrm{Trp}^{6}, \mathrm{Pro}^{9}, \mathrm{NEt}\right.$ LRF. Life Sci. 25, 1065-1074.

Vale, W., Rivier, C., Rivier, J. \& Brown, M. (1977) Diverse role of hypothalamic regulatory peptides. In Medicinal Chemistry, vol. 5, pp. 25-62. Ed. J. Mathieu. Elsevier Scientific, Amsterdam.

Vickery, B.H. \& McRae, G.I. (1980) Synchronization of oestrus in adult female rats by utilizing the paradoxical effects of an LH-RH agonist. J. Reprod. Fert. 60, 399-402.

Wildt, L., Hausler, A., Marshall, G., Hutchinson, J.S., Plant, T.M., Belchetz, P.E. \& Knobil, E. (1981) Frequency and amplitude of gonadotropin-releasing hormone stimulation and gonadotropin secretion in the rhesus monkey. Endocrinology 109, 376-385. 